\title{
KONSEP AGAMA SUKU WANA TENTANG KEMATIAN, IMPLIKASINYA BAGI MISI KRISTEN DI WANA
}

\author{
Ronaldy Dada ${ }^{1}$, Ermin Alperiana Mosooli ${ }^{2}$ \\ Sekolah Tinggi Teologi Star's Lub Luwuk Banggai \\ ronaldy.dd@gmail.com
}

\begin{abstract}
Wana, one of the tribes in Central Sulawesi, has a custom of demolishing houses and moving when one of the inhabitants dies. This custom is an expression of their fear of death. In theory, cultural activities around death are always associated with religious concepts. This study aims to explore the religious ideas behind the habits. The research method used was an ethnographic study using interview as data collection techniques. Informants are 8 (eight) original Wana people. Data is analyzed through reduction, display, and conclusions/verification. The results show that the custom is related to the religious concept they professed regarding death. According to the Wana, death is related to Pue, the end of everything, and caused by evil spirits. The purpose of dismantling the house and moving after death is to avoid the influence of evil spirits against the living. For Christian mission activities that want to contribute to the development in Wana, the results shows that religious concept needs to be transformed through a contextual approach.
\end{abstract}

Keywords: tribe religion, Wana, fear of death, nomad, Pue

\begin{abstract}
Abstrak. Wana, salah satu suku di Sulawesi Tengah, memiliki kebiasaan membongkar rumah dan berpindah bila salah satu penghuninya meninggal dunia. Ini merupakan ekspresi atas ketakutan mereka terhadap kematian. Menurut teori, kegiatan kultural seputar kematian selalu terkait dengan konsep keagamaan. Penelitian ini bertujuan menggali konsep religi di balik kebiasaan tersebut. Metode penelitian yang digunakan adalah studi etnografi dengan menggunakan teknik pengambilan data wawancara. Informan adalah orang suku Wana asli sebanyak 8 (delapan) orang. Data dianalisa dengan menggunakan teknik reduksi data, display data, dan kesimpulan/verifikasi. Hasil penelitian menunjukkan bahwa kebiasaan tersebut terkait dengan konsep agama yang mereka anut mengenai kematian. Menurut orang Wana, kematian berkaitan dengan Pue, merupakan akhir dari segalanya, dan disebabkan oleh roh jahat. Tujuan membongkar rumah dan berpindah setelah terjadi kematian adalah untuk menjauhi pengaruh roh jahat terhadap orang yang masih hidup. Bagi kegiatan misi Kristen yang ingin ikut berkontribusi dalam pembangunan suku Wana, hasil penelitian ini menunjukkan perlu adanya transformasi dalam konsep keagamaan tersebut melalui suatu pendekatan yang kontekstual.
\end{abstract}

Kata Kunci: agama suku, suku Wana, ketakutan terhadap kematian, nomaden, Pue

Dalam sejarah pekabaran Injil di Indonesia, Wana merupakan salah satu suku yang mendapat perhatian dari para misionaris. Injil diperkirakan masuk di Wana sejak tahun 1926 sebagai buah dari kegiatan misi yang 
dirintis oleh A. C. Kruyt dan N. Adriani di Poso (STT GKST, 2018). Saat ini agama Kristen telah menjadi salah satu agama dominan di suku Wana selain Islam dan Halaik (agama suku Wana) (Hisyam, 2015).

Wana adalah salah satu suku di Sulawesi Tengah yang pemukimannya tersebar di bagian timur dan timur laut Morowali sampai bagian barat pegunungan Batui di sekitar gunung Tokala (Kab. Banggai) dan pegunungan Balingara, dataran Bulan dan Gunung Lumut di Kab.Tojo Una-una." (Pitopang \& Safarudin, n.d.). Hingga saat ini, sebagian besar mereka masih hidup nomaden (Kabaralam.com, 2018) dan tergolong sebagai Komunitas Adat Terpencil (KAT) ${ }^{1}$. KAT yang hidup nomaden seperti ini adalah yang taraf hidupnya paling rendah. Sebab itu salah satu tujuan dari pemberdayaan sosial yang dilakukan pemerintah terhadap KAT adalah integrasi dengan sistem sosial yang lebih luas. (Permensos 12/2015, 2015). Mereka diharapkan bisa hidup menetap.

Upaya pemberdayaan suku yang demikian sejalan dengan tujuan misi Kristen. Sebab seperti dikemukakan oleh Bosch bahwa salah satu unsur dari paradigma misi oikemenis adalah misi sebagai perjuangan demi keadilan. Dalam unsur ini, misi bukan hanya berkaitan dengan halhal yang rohani, tapi juga menyangkut masalah-masalah sosial (Bosch, 2009). Lalu bagaimana cara para pekerja misi di suku Wana terlibat dalam upaya pengitegrasian mereka ke dalam komunitas sosial yang lebih luas?

1 KAT adalah sekumpulan orang dalam jumlah tertentu yang terikat oleh kesatuan geografis yang kondisinya miskin, terpencil, dan/atau rentan sosial ekonomi (Perpres 186/2014, 2014). 
Jawaban atas pertanyaan tersebut harus dimulai dari suatu kajian tentang penyebab komunitas ini masih menjalankan pola hidup berpencar dan berpindah-pindah. Hasil dari kajian ini yang akan memberikan masukan untuk merumuskan strategi misi yang perlu ditempuh.

Pada umumnya, faktor yang biasanya dikemukakan sebagai penyebab pola hidup nomaden pada KAT adalah ekonomi. KAT yang memiliki teknologi sederhana sangat mengandalkan alam sebagai sumber makanan. Jika ketersediaan makanan menipis di wilayah tempat mereka hidup, maka mereka akan berpindah untuk mencari sumber makanan yang baru. (Noor, Yusliani, \& Mansyur, 2015). Ini terjadi baik pada KAT daerah di pegunungan maupun yang hidup di pulau-pulau kecil (Sari \& Pratiwi, 2018).

Namun pada suku Wana, ada juga faktor lain turut berpengaruh. Di suku ini bila ada penghuni rumah yang meninggal dunia maka mereka akan membongkar rumah yang mereka tinggali dan berpindah jauh dari situ. Ini merupakan salah satu kebiasaan mereka sehingga turut berkontribusi terhadap pola hidup mereka yang berpencar dan berpindahpindah.

Gambar 1. Rumah Orang Wana

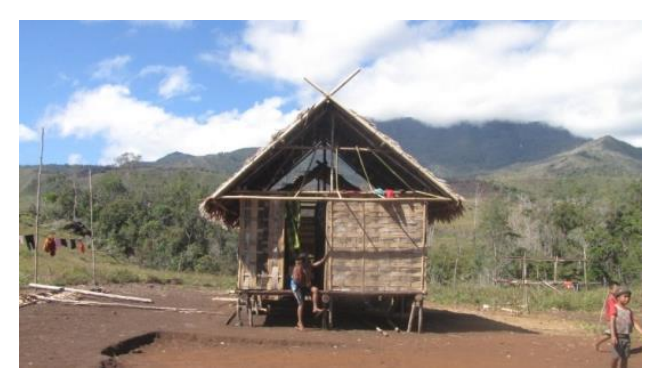


Moore dan Williamson mengemukakan perilaku seperti ini merupakan reaksi paling dasar manusia terhadap kematian. Keduanya mengutip Herzog (1983) yang memaparkan hasil penelitian terhadap beberapa suku pra-aksara di Malaysia dan India Utara yang selalu lari meninggalkan tempat tinggal mereka dan tidak pernah kembali bila salah satu anggota kelompok mereka meninggal dunia. Herzog menjelaskan perilaku ini sebagai kengerian karena menyaksikan perubahan yang tidak bisa dijelaskan dari seseorang yang hidup menjadi mati. (Moore \& Williamson, 2003).

Ketakutan terhadap kematian sebenarnya merupakan fenomena universal. Nottingham mengatakan ini disebabkan manusia pada dasarnya ingin hidup lebih lama. Kematian tidak bisa diramalkan kapan waktunya (kecuali orang bunuh diri) dan berada di luar jangkauan kekuasaan mereka. (Nottingham, 1997). Manusia juga, pada dasarnya, selalu mengharapkan adanya kepastian dan jaminan rasa aman. Namun, di dalam masalah kematian, manusia harus tunduk dalam ketidakpastian (Handayani dalam Wicaksono \& Meiyanto, 2003).

Agama, diakui para ahli, merupakan jawaban paling efektif dalam menghadapi ketakutan terhadap kematian. Ellis dan Wahabi (2012) memaparkan adanya empat teori terkait hubungan antara agama dengan ketakutan terhadap kematian. Pertama, buffering theory. Menurut teori ini, kebanyakan agama menjamin adanya kehidupan yang bahagia setelah 
kematian bagi pemeluknya, sejauh mereka taat pada aturan agama. Ini membantu para pemeluknya mengatasi ketakutan terhadap kematian.

Kedua, terror-management theory. Teori ini menyatakan bahwa perenungan personal mengenai kematian dapat menimbulkan ketakutan bahkan kepanikan dalam diri seseorang. Jaminan agama tentang kehidupan yang abadi, membuat orang yang beragama cenderung tidak terlalu takut terhadap kematian dibandingkan dengan orang yang tidak beragama. Jadi, dalam hal ini agama berfungsi mengurangi terror yang dirasakan manusia dalam menghadapi kematian.

Ketiga, curvilinearity theory. Teori ini melihat hubungan antara agama dan ketakutan kepada kematian bersifat melengkung (curvilinear). Di titik yang satu adalah orang yang taat beragama yang percaya pada kehidupan setelah kematian. Orang ini tidak takut pada kematian. Di titik yang satunya lagi adalah orang yang tidak beragama yang tidak percaya akan adanya kehidupan setelah kematian sehingga mereka memiliki sedikit alasan untuk takut pada kematian. Titik yang di tengah adalah orang-orang yang beragama tetapi kurang sungguh-sungguh. Mereka inilah yang paling takut terhadap kematian sebab mereka tidak terlalu yakin tentang adanya kehidupan setelah kematian.

Keempat, death apprehension (DA) theory. Teori ini mengemukakan bahwa agama berkontribusi untuk memperkuat ketakutan manusia terhadap kematian. Orang yang beragama jauh lebih takut terhadap kematian. Ini disebabkan agama-agama tersebut mengajarkan Ronaldy Dada, Ermin Alperiana Mosooli 
bahwa setelah kematian seseorang bisa mendapatkan hal yang sangat baik, yaitu keabadian di surga, atau hal yang sangat buruk, yaitu keabadian di neraka, dan tanpa ada kesempatan kedua. Ketakutan ini semakin besar jika agama juga mengajarkan bahwa Tuhan itu menuntut, membalas dendam, dan memberikan hukuman dibandingkan memberikan pengampunan.

Dari keempat teori yang dipaparkan Ellis dan Wahabi di atas dapat disimpulkan bahwa hubungan antara agama dan ketakutan terhadap kematian tergantung pada: apa isi ajaran agamanya, sejauh mana kepercayaan pemeluknya terhadap ajaran tersebut, serta sejauhmana tingkat ketaatan mereka terhadapnya. Artinya, jika seseorang menganut suatu agama yang mengajarkan adanya kehidupan setelah kematian, kemudian dia mempercayai dan taat pada ajaran tersebut, maka ketakutannya kepada kematian akan berkurang.

Terkait dengan kebiasaan suku Wana yang membongkar rumah dan berpindah rumah setelah terjadi kematian, pertanyaan yang menarik untuk diajukan adalah: seperti apa konsep agama mereka terkait dengan kematian? Mengapa konsep agama ${ }^{2}$ yang mereka miliki tidak mendorong

${ }^{2}$ Agama merupakan istilah yang pengertiannya cukup kompleks (Lih. Marzali, 2017). Di Indonesia istilah agama malah menjadi polemik hukum (Febionesta, 2019). Istilah agama dalam tulisan ini merujuk kepada pengertian religi yang dikemukakan Koentjaraningrat. Menurut Koentjarangrat ada empat komponen pembentuk religi, yaitu: (1) Emosi keagamaan atau getaran jiwa yang menyebabkan manusia menjalankan kelakuan keagamaan; (2) Sistem kepercayaan atau bayangan-bayangan manusia tentang bentuk dunia, alam, alam gaib, hidup, maut, dan sebagainya; (3) Sistem upacara keagamaan yang bertujuan mencari hubungan dengan dunia gaib berdasarkan atas sistem kepercayaan tersebut; (4) Kelompok keagamaan atau kesatuan-kesatuan sosial Ronaldy Dada, Ermin Alperiana Mosooli 
mereka menghadapi kematian, bertahan, tidak harus membongkar rumah dan berpindah jauh dari situ?

Tujuan penelitian ini adalah untuk menggali konsep agama mengenai kematian yang dimiliki suku Wana yang mendasari perilaku mereka membongkar rumah dan berpindah pasca kematian. Hasilnya dapat bermanfaat bagi pemerintah dalam program pemberdayaan masyarakat Wana maupun bagi para pekerja misi yang aktif melakukan pelayanan di Wana.

\section{METODE}

Penelitian ini merupakan penelitian deskriptif yang digambarkan Sugiyono sebagai penelitian yang rumusan masalahnya berkenaan dengan variabel mandiri, tidak dibuat perbandingan dengan variabel yang lain, atau mencari hubungan dengan variabel lain (Sugiyono, 2018). Variabel mandiri yang dimaksud dalam penelitian ini adalah konsep agama suku Wana di balik kebiasaan membongkar rumah dan berpindah pasca kematian.

Metode penelitian yang digunakan adalah etnografi. Menurut Creswell (2012, p. 462), "etnografi adalah prosedur penelitian kualitatif untuk menggambarkan, menganalisa, dan menafsirkan unsur-unsur dari sebuah kelompok budaya seperti pola perilaku, kepercayaan,

yang mengonsepsikan dan mengaktifkan religi beserta sistem upacara-upacara keagamaannya (Koentjaraningrat, 1992). Dari keempat komponen tersebut, pembahasan mengenai konsep keagamaan mengenai kematian dalam agama suku Wana lebih menekankan pada komponen yang kedua. 
dan bahasa yang berkembang dari waktu ke waktu." Tujuannya adalah menemukan sudut pandang penduduk asli (native) mengenai hal tertentu. Dalam rangka itu maka seorang etnografer akan mengamati penduduk asli tersebut, mendengarkan mereka, lalu membuat kesimpulan (Spradley, 2007). Teknik pengambilan data adalah wawancara kepada para informan. Teknik analisa data menggunakan konsep Miles dan Huberman yaitu aktivitas reduksi data, display data, dan kesimpulan/verifikasi. (Sugiyono, 2018).

Dalam penelitian ini peneliti akan menggali pemahaman orang Wana asli mengenai konsep religi yang mendasari kebiasaan mereka membongkar rumah dan berpindah jauh setelah terjadi kematian. Langkah-langkah yang akan ditempuh adalah: mewawancarai informan, menganalisa hasil wawancara untuk menemukan konsep-konsep (tematema) utama, menilai dan menginterpretasi konsep-konsep tersebut, dan terakhir menemukan implikasinya bagi kegiatan misi Kristen di Wana.

Penelitian dilakukan pada bulan Januari-Maret 2018 di desa Taronggo, sebuah desa di kecamatan Bungku Utara, kabupaten Morowali Utara, Sulawesi Tengah yang merupakan desa yang dihuni orang Wana. Informan yang dilibatkan dalam penelitian ini berjumlah 8 (delapan) orang yang semuanya merupakan suku Wana asli yang tinggal di desa Taronggo. Empat perempuan dan empat laki-laki. Tujuh di antaranya sudah menyatakan diri memeluk agama Kristen, dan satu di antaranya 
beragama Islam. Dari segi ketokohan di masyarakat, empat di antaranya adalah aparat desa.

Tabel 1. Data Informan

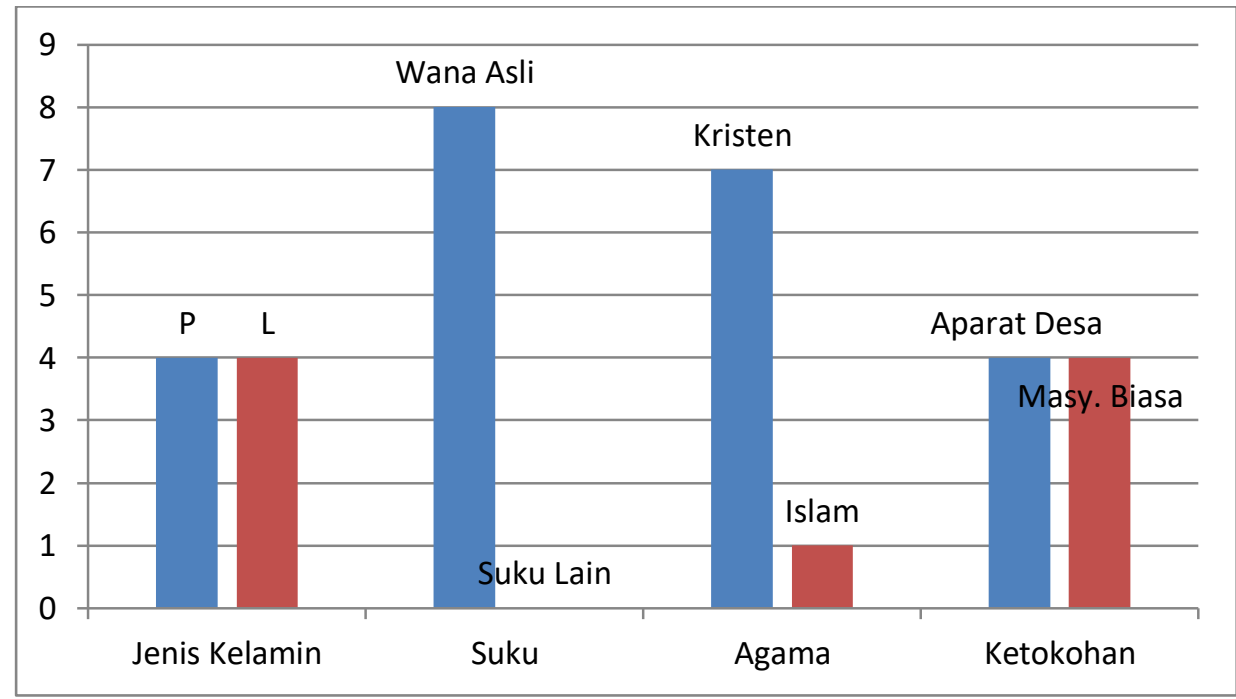

\section{HASIL}

Secara garis besar konsep religi mengenai kematian pada masyarakat suku Wana yang ditemukan dalam penelitian ini adalah: 1) kematian berkaitan dengan Pue atau Tuhan; 2) kematian adalah akhir dari segalanya; 3) kematian itu menakutkan dan disebabkan oleh roh jahat; 4) bongkar rumah dan pindah untuk menjauhi roh jahat. Berikut adalah uraian hasil penelitian berdasarkan wawancara dengan para informan.

\section{Pue dan Kematian}

Hisyam (2015), dalam penelitiannya mengenai Halaikh yaitu sistem kepercayaan suku Wana, menyebutkan bahwa orang Wana percaya kepada Pue sebagai Tuhan yang esa dan mahakuasa. Para informan 
dalam penelitian ini juga menyebutnya "Pue atau Tuhan". Berarti Pue, bagi orang Wana adalah Tuhan.

Namun demikian, sebagian informan mengakui bahwa sebenarnya identitas Pue bagi orang Wana tidaklah terlalu jelas, terutama dalam kaitan dengan kematian. Di satu sisi, mereka memahami Pue sebagai tujuan kembalinya manusia setelah mati. Mati bagi manusia berarti "kembali kepada Pue". Artinya orang Wana meyakini bahwa Pue adalah asal (source, origin) kehidupan manusia dan pemilik manusia.

Namun di sisi lain, Pue juga mereka pahami sebagai roh tahayul atau roh jahat atau kuasa kegelapan yang mereka sembah di batu, di goa, atau di pohon. Pue dalam realitas roh jahat inilah yang menyebabkan kematian pada manusia. Salah seorang informan menjelaskan bahwa “... suku Wana memandang kematian itu terjadi karena sudah ada roh jahat yang tinggal dalam hidup seseorang dan menguasai hidupnya sehingga ... kematian itu akibat dari roh jahat."

Di sini nampak bahwa pemahaman mereka tentang identitas Pue terkait dengan kematian bersifat ambivalen atau kontradiktif.

\section{Kematian adalah Akhir dari Segalanya}

Ke mana manusia pergi setelah kehidupannya berakhir di dunia ini? Menurut informan, bagi orang Wana, "setelah kematian manusia akan pergi ke yausuruga dengan dituntun oleh Pue melalui suatu upacara adat kematian." Adat kematian yang dimaksud di atas adalah momata, yaitu 
upacara kematian yang dilakukan untuk memperingati kematian seseorang.

Yausuruga adalah tempat perhentian terakhir. Salah seorang informan mengatakan, “... menurut suku Wana setelah mereka mati tidak ada lagi kelanjutannya atau tidak ada lagi proses mengenai kematian yang mereka alami." Dengan melakukan adat kematian, "mereka akan langsung pergi ke yausuruga."

Tampaknya yausuruga adalah tempat yang baik. Orang berdosa atau jahat sekalipun bisa sampai ke sana jika dihantar dalam suatu upacara adat. Namun yausuruga adalah tempat perhentian, bukan kelanjutan kehidupan yang baru.

\section{Kematian Itu Menakutkan}

Kematian bagi orang Wana adalah fenomena yang sangat menakutkan. Ketakutan tersebut berasal dari keyakinan bahwa, "jika orang mati tidak cepat dikuburkan maka roh jahat atau setan akan datang pada rumah yang didiami orang mati itu."

Sebab itu, jika terjadi kematian maka mayat orang tersebut segera mereka kuburkan dan rumah tempat kematiannya segera dibongkar seperti diungkapkan salah seorang informan berikut ini:

"Jika ada masyarakat suku Wana yang mati mayatnya langsung dikuburkan karena mereka sangat takut pada orang mati, mereka beranggapan bahwa jika orang mati tidak cepat dikuburkan maka roh jahat atau setan akan datang pada rumah yang didiami orang mati itu. Setelah dikuburkan mereka langsung membongkar tempat 
tinggal orang yang sudah mati. Alasannya bahwa rumah tersebut sudah ada setannya."

Jadi, hal yang mereka takuti dari fenomena kematian adalah kehadiran roh jahat. Roh itu mengakibatkan kematian dan akan segera mendiami rumah tempat orang mati. Tampaknya ketakutan yang sebenarnya adalah kehadiran roh jahat akan mengakibatkan kematian berikut pada orang lain yang ada dalam rumah.

\section{Bongkar Rumah dan Pindah setelah Kematian}

Ketakutan orang Wana pada kehadiran roh jahat dalam kejadian kematian membawa perubahan besar dalam hidup orang yang masih hidup dan tinggal serumah dengan orang yang sudah mati itu. Mereka harus membongkar rumah dan pindah membuat rumah di tempat lain yang jauh dari rumah sebelumnya.

Dua informan mengakui bahwa kebiasaan orang Wana membongkar rumah dan pindah jauh setelah kematian merupakan dampak negatif dari konsep mereka tentang kematian. "Di dalam kehidupan Suku Wana mengenai kematian akan banyak dampak negatif yang terjadi salah satunya mereka akan membongkar rumah atau tempat tinggal mereka sampai rusak setelah mereka bongkar mereka akan berpindah ke tempat lain." Anggapan utamanya adalah: "ada roh jahat yang tinggal di dalam rumah mereka." 
Bagan 1. Konsep Agama Suku Wana tentang Kematian

Positif:

- Sumber kehidupan

- Penolong

- Pelindung

- Berdaulat

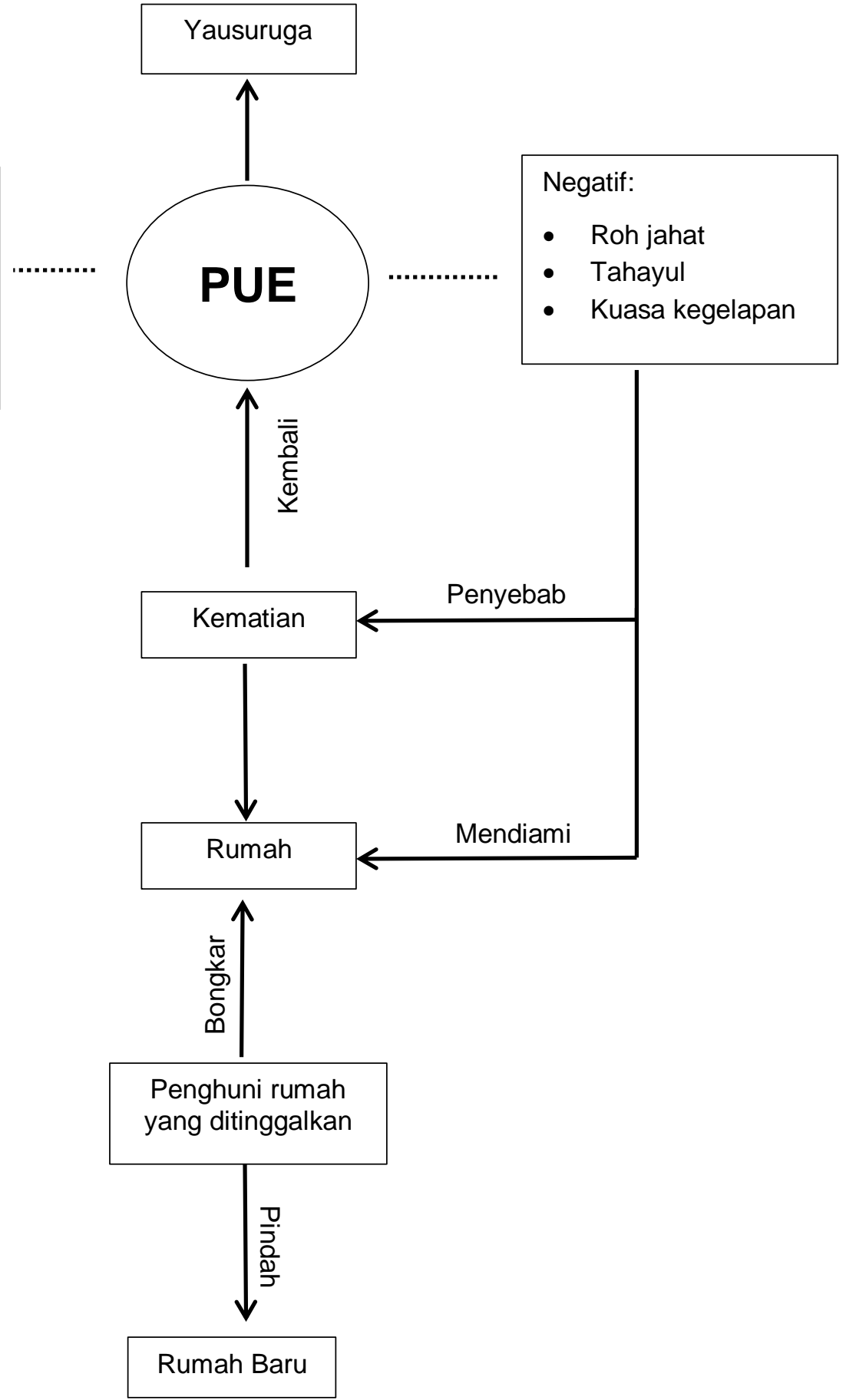




\section{PEMBAHASAN}

\section{Konsep Religi dan Ketakutan Orang Wana Terhadap Kematian}

Hasil penelitian menunjukkan bahwa kebiasaan orang Wana membongkar rumah dan berpindah pasca kematian salah seorang penghuni rumah sangat dipengaruhi oleh konsep agama yang mereka anut. Kematian disebabkan oleh roh jahat. Jika roh ini datang dan mendiami rumah mereka maka akan terjadi kematian di sana. Sebab itu rumah harus dibongkar dan ditinggalkan oleh penghuni yang masih hidup agar mereka tidak mengalami nasib yang sama. Tindakan ini untuk memutus pengaruh roh jahat tersebut kepada penghuni yang masih hidup.

Kenyataan ini menunjukkan bahwa religi orang Wana terkait dengan kematian belum memfasilitasi mereka untuk menghadapi teror atau ketakutan terhadap kematian. Paling tidak ada tiga faktor yang dapat diidentifikasi sebagai penyebabnya seperti dalam uraian berikut.

Pertama, ambivalensi pemahaman tentang otoritas Pue atas kehidupan manusia.

Dalam penelitiannya tentang Halaikh yaitu agama suku Wana, Hisyam menyimpulkan bahwa Pue dipahami sebagai Tuhan. Dia adalah penguasa tertinggi yang menguasai jagad raya dengan segala isinya. la tidak hanya mengatur dan menguasai, tetapi juga yang menciptakan segala sesuatu yang ada di jagat raya ini. (Hisyam, 2015) 
Namun dalam penelitian ini, dalam kaitan dengan masalah kematian, para informan memberikan gambaran yang ambivalen atau dualis tentang Pue. Di satu sisi Pue adalah pemilik kehidupan, tujuan manusia kembali setelah kematian. Namun di sisi lain, Pue adalah roh jahat yang dapat mengambil nyawa manusia.

Pemahaman orang Wana yang ambivalen tentang Pue tampaknya bisa dimengerti dari penjelasan Dhavamony berikut ini. Menurut Dhavamony dalam sejarah agama terdapat banyak mitos yang menerangkan dunia dan keadaan manusia lewat suatu sistem perlawanan dan ketegangan, yang pada hakekatnya bertujuan untuk memberikan arti tentang seluruh realitas. Dualisme seperti ini tampak jelas dalam konsep ketuhanan. Salah satu contohnya adalah mitologi dalam agama Vedis tentang pertarungan antara Indra melawan Vrtra, pemimpin para Asura, iblis yang memenjarakan air, tuan dari sembilan puluh sembilan benteng. Hasil dari pertempuran ini adalah: air dibebaskan, matahari dibuat bersinar, dan sapi-sapi milik Vrtra dilepaskan. Indra menjadi yang terbesar di antara para dewa. (Dhavamony, 1995). Dhavamony menyimpulkan bahwa,

seluruh konflik antara Indra dan Vrtra menjelaskan dengan gamblang karakter ambivalen dari yang Ilahi, yang murah hati dan menakutkan, kreatif dan destruktif, yang nyata dan yang tersembunyi. Apa yang ditampilkan sebagai yang berlawanan, tidak sempurna, jahat, bersifat iblis, menampilkan aspek negatif dari realitas. $(1995$, p. 139) 
Pertarungan antara karakter yang ambivalen ini selalu dimenangkan oleh karakter yang baik. Pemenang akan menjadi penguasa sehingga kebaikanlah yang akan menjadi tatanan realitas.

Dalam religi orang Wana, ambivalensi tersebut tidak tampak dalam suatu pertarungan antara yang Baik dan yang jahat. Karena tidak ada pertarungan maka tidak ada pemenang. Ada Pue yang memiliki otoritas sebagai tujuan manusia kembali setelah mati, tapi ada juga Pue yang dapat mengambil nyawa manusia. Pue yang pertama adalah yang baik, sedangkan kedua adalah yang jahat. Pue yang Baik tidak berkuasa atas yang jahat.

Dalam kaitan dengan kematian, otoritas Pue yang Baik itu tidak terlihat. Seolah-olah tidak ada campur tangan-Nya dalam masalah kematian. la hanya menjadi tujuan untuk kembali. Akibatnya manusia menjadi begitu rapuh dan lemah di hadapan ancaman roh jahat yang setiap saat bisa mendatangkan kematian bagi mereka. Membongkar rumah dan pindah jauh dari situ adalah tindakan lari dari menjauhi roh jahat yang tidak mampu dihadapi oleh manusia itu.

Kedua, pemahaman tentang kedaulatan Pue atas kehidupan dan kematian

Dalam pemahaman orang Wana, Pue yang baik bukanlah penentu kematian seseorang. Dia bukan penyebab dan tidak berdaulat atas kematian. Secara logika, ini sangat mungkin berpengaruh terhadap tingkat 
penerimaan orang Wana terhadap kematian. Seandainya mereka mengakui kedaulatan Pue atas kematian, sangat mungkin mereka dapat menerima kematian sebagai hal yang wajar.

Hal ini bisa dibandingkan dengan kepercayaan Kristen mengenai kedaulatan Allah atas kehidupan manusia. Tolanda dan Maiaweng menjabarkan makna kedaulatan Allah dengan: "Allah melakukan apa yang dikehendaki-Nya hanya karena semuanya adalah milik-Nya. Allah adalah penyebab atau memperkenankan terjadinya segala sesuatu baik yang ada di surga maupun yang ada di bumi." (2011, p. 56). Terhadap kisah Ayub yang merupakan bukti dari kedaulatan Allah, mereka menulis:

Itulah sebabnya di dalam keluh kesah Ayub terhadap pencobaan yang dialaminya (Ayub 1:21), ia berkata: "Dengan telanjang aku keluar dari kandungan ibuku, dengan telanjang juga aku akan kembali ke dalamnya. TUHAN yang memberi, TUHAN yang mengambil, terpujilah nama TUHAN!" Ayub menyadari bahwa Allah adalah Allah yang berdaulat secara mutlak untuk memberkati dia dengan berlimpah, dan juga untuk mengambil kembali apa yang telah la berikan dengan cara dan waktu yang tidak pernah, tidak perlu, dan tidak ada keharusan bagi-Nya untuk mengkomunikasikan kepada siapa la akan melakukan-Nya. Ayub tahu bahwa kalau Tuhan berkuasa untuk memberi, maka la pasti juga berkuasa untuk mengambilnya kembali. Dalam keluh kesahnya, Ayub tidak menyalahkan atau menuduh lblis yang melakukan semuanya. la menyadari bahwa bukanlah lblis yang berkuasa tetapi Allah, karena Iblis tidak dapat berbuat sesuatu apapun jika Tuhan tidak mengizinkannya. (2011, p. 74).

Orang Wana belum mengakui kedaulatan Pue yang Baik dalam kehidupan mereka, seperti halnya ajaran Kristen mengakui kedaulatan Allah berdasarkan kitab Ayub tersebut. 
Ketiga, konsep tentang yausuruga

Seperti dikemukakan Ellis dan Wahab, dalam teori tentang hubungan agama dengan ketakutan terhadap kematian, kepercayaan akan adanya kehidupan setelah kematian adalah keyakinan yang sangat efektif untuk menghadapi ketakutan terhadap kematian. (Ellis \& Wahab, 2012). Orang Wana meyakini bahwa orang mati akan kembali kepada Pue dan tempatnya adalah di yausuruga. Namun tampaknya yausuruga adalah benar-benar tempat perhentian. Tidak ada kelanjutan kehidupan di sana. Yausuruga juga tidak digambarkan sebagai tempat yang menyenangkan, tempat di mana manusia akan menjalani hidup bahagia bersama Pue.

Ini berbeda dengan keyakinan Kristen. Orang Kristen, menurut Choudry dkk, tidak takut mati. Mereka percaya pada kebangkitan orang mati: masa depan yang telah ditentukan oleh kebangkitan Kristus. (Yoh. 11: 25-26). Kristus, melalui kebangkitan-Nya dari kematian, telah menaklukkan maut, dan membuka kehidupan abadi dalam persekutuan dengan Allah. (I Kor 15: 54-55). (Choudry, Latif, \& Warburton, 2018)

\section{Implikasi Bagi Misi Kontekstual Kristen di Suku Wana}

Kegiatan misi Kristen di suku Wana sangat potensial dalam mendukung komunitas Wana yang masih hidup nomaden untuk menetap. Hal penting yang dapat dilakukan adalah transformasi konsep keagamaan mereka mengenai kematian. Meskipun demikian perlu pendekatan yang mempertimbangkan kekayaan dan kekuatan budaya setempat. 
Kritik yang biasa ditujukan kepada kegiatan misi Kristen untuk KAT adalah mental superior. Hisyam menunjukkan bahwa di suku Wana, superioritas tampak dari pelabelan atau penyebutan kafir kepada kepercayaan orang Wana. Lama kelamaan penyebutan seperti ini menumbuhkan sikap resistensi. Orang Wana merasa diperlakukan kasar bila disebut orang kafir. (Hisyam, 2015)

Pendekatan yang sesuai tampaknya adalah teologi kontekstual model antropologi, salah satu model teologi kontekstual yang dikemukakan Bevans. Menurut Bevans, presuposisi utama model antropologi adalah sebagai berikut:

Mereka mengakui dan menekankan kebaikan manusia dan budayanya. Budaya dilihat sebagai tempat di mana Allah menyatakan diri. Kita seharusnya menemukan Kristus yang tersembunyi dalam suatu budaya daripada membawa Kristus ke dalam budaya tersebut. Model antropologi melihat manusia dan budayanya sebagai hal yang kudus. Di dalam diri manusia dan budayanya, bukan hanya terdapat jalan untuk menyampaikan berita Injil tapi berita Injil itu sesungguhnya ditemukan di dalam budaya itu sendiri. (Bevans, 1985).

Dengan teologi kontekstual model antropologi ini maka yang perlu diperkuat dalam religi suku Wana terkait dengan kematian adalah: (1) otoritas Pue yang Baik atas seluruh aspek kehidupan manusia, (2) kedaulatan Pue atas kematian manusia, (3) kehidupan setelah kematian bersama Pue di yausuruga.

Keterbatasan penelitian. Penelitian ini memiliki beberapa keterbatasan yang perlu ditindaklanjuti dengan penelitian selanjutnya. 
Pertama: para informan umumnya sudah memeluk agama Kristen. Mereka sudah menempatkan diri sebagai outsider dalam religi orang Wana dan hal tersebut bisa menimbulkan bias dalam mereka memahami dan menjelaskan tentang realitas Pue. Kedua: jumlah informan yang terbatas juga bisa menyebabkan gambaran yang kurang komprehensif tentang konsep religi orang Wana mengenai kematian.

\section{KESIMPULAN}

Konsep religi orang Wana mengenai kematian turut mempengaruhi tindakan mereka membongkar rumah dan berpindah jauh dari situ jika terjadi kematian pada salah satu penghuni. Pengaruh itu terletak pada konsep mereka tentang Pue, kedaulatan Pue atas kehidupan manusia, dan yausuruga sebagai tempat perginya seseorang setelah kematian. Jika konsep religi ini mengalami transformasi sangat mungkin akan mendukung orang Wana untuk menjalani pola hidup menetap. Salah satu manfaat penting dari pola hidup menetap ini adalah mereka bisa menikmati pembangunan yang digalakkan pemerintah Indonesia untuk Komunitas Ada Terpencil (KAT).

Salah satu pihak yang bisa melakukan transformasi adalah para pekerja misi Kristen yang aktif pelayanan di suku Wana. Pendekatan yang diperlukan adalah suatu pendekatan teologi kontekstual yang memperhitungkan kekayaan dan kekuatan religi dan budaya suku Wana. 


\section{DAFTAR PUSTAKA}

Bevans, S. (1985). Models Of Contextual Theology. Missiology: An International Review, 13(2), 185-201.

Bosch, D. J. . (2009). Transformasi Misi Kristen. Jakarta: BPK Gunung Mulia.

Choudry, M., Latif, A., \& Warburton, K. G. (2018). An overview of the spiritual importances of end-of-life care among the five major faiths of the United Kingdom. Clinical Medicine, Journal of the Royal College of Physicians of London. https://doi.org/10.7861/clinmedicine.18-1-23

Cresswell, J. W. (2012). Research design Pendekatan kualitatif, Kuantitatif dan Mixed; Cetakan ke-2, Yogyakarta: Pustaka Pelajar.

Dhavamony, M. (1995). Fenomenologi Agama. Yogyakarta: Kanisius.

Ellis, L., \& Wahab, E. a. (2012). Religiosity and Fear of Death: A TheoryOriented Review of the Empirical Literature. Review of Religious Research, 55(1), 149-189. https://doi.org/10.1007/s13644-012-00643

Febionesta. (2019). Miskonsepsi Pengakuan Agama di Indonesia. Retrieved from https://ylbhi.or.id/ website: https://ylbhi.or.id/publikasi/artikel/miskonsepsi-pengakuan-agama-diindonesia/

Hisyam, M. (2015). Halaik: Agama Orang Taa Vana. Jurnal Masyarakat \& Budaya, 17(2), 153-170.

Kabaralam.com. (2018). Kehidupan Suku Wana di Hutan Adat Morowali. Hasil Inventarisasi BKSDA Sulawesi Tengah. Retrieved December 5, 2019, from Kabaralam.com website: https://www.kabaralam.com/berita/2018-02-18/kehidupan-suku-wanadi-hutan-adat-morowali

Koentjaraningrat. (1992). Beberapa Pokok Antropologi Sosial. Jakarta: PT Dian Rakyat.

Marzali, A. (2017). Agama dan Kebudayaan. Indonesian Journal of Anthropology. https://doi.org/10.24198/umbara.v1i1.9604

Moore, C. C., \& Williamson, J. B. (2003). The universal fear of death and the cultural response. In Handbook of Death and Dying. https://doi.org/10.4135/9781412914291.n1

Noor, Yusliani, \& Mansyur. (2015). Menelusuri Jejak-jejak Masa Lalu 
Indonesia. Retrieved from http://eprints.ulm.ac.id/1225/

Nottingham, E. K. (1997). Agama dan Masyarakat: Suatu Pengantar Sosiologi Agama. Jakarta: RajaGrafindo Persada.

Permensos 12/2015. (2015). Pelaksanaan Peraturan Presiden Nomor 186 Tahun 2014 Tentang Pemberdayaan Sosial Terhadap Komunitas Adat Terpencil. Jakarta: Berita Negara Republik Indonesia Tahun 2015 Nomor 1279.

Perpres 186/2014. (2014). Peraturan Presiden Republik Indonesia Nomor 186 Tahun 2014 Tentang Pemberdayaan Sosial Terhadap Komunitas Adat Terpencil.

Pitopang, R., \& Safarudin. (n.d.). Sistem Etnoekologi Masyarakat "Tao Taawana" Di Cagar Alam Morowali, Sulawesi Tengah, Indonesia. Academia.Edu.

Sari, M. E. P., \& Pratiwi, D. A. (2018). Faktor-Faktoryang Mempengaruhi Kesejahteraan Hidup Masyarakat Suku Laut Pulau Bertam Kota Batam. Jurnal Trias Politika, 2(2), 1-16.

Spradley, J. P. (2007). Metode Etnografi (edisi ke-2). Yogyakarta: Tiara Wacana.

STT GKST. (2018). Sejarah Singkat GKST. Retrieved December 5, 2019, from www.sttgkst.ac.id website: http://www.sttgkst.ac.id/

Sugiyono. (2018). Metode Penelitian Kuantitatif, Kualitatif, dan $R \& D$. Bandung: Alfabeta.

Tolanda, I., \& Maiaweng, P. C. D. (2011). Kedaulatan Allah Atas Iblis Berdasarkan Kitab Ayub Pasal 1 Dan 2 Serta Relevansinya Dalam Kehidupan Orang Percaya. Jurnal Jaffray. https://doi.org/10.25278/jj71.v9i2.96

Wicaksono, W., \& Meiyanto, S. (2003). Ketakutan Terhadap Kematian Ditinjau dari Kebijaksanaan dan Orientasi Religius pada Periode Remaja Akhir yang Berstatus Mahasiswa. Jurnal Psikologi, 1, 57-65. 